\title{
Inovasi Adaptif Pembelajaran Sekolah Arsitektur dalam Tatanan Baru
}

\author{
Shanty Silitonga \\ Program Studi Arsitektur, Fakultas Teknik, Universitas Katolik Santo Thomas, Medan \\ Email: shanty_silitonga@ust.ac.id; shanty.silitonga@gmail.com
}

\begin{abstract}
Abstrak
Kondisi pandemi Covid-19 saat ini telah membawa banyak perubahan dalam tatanan masyarakat kita, termasuk perubahan dalam tatanan pembelajaran. Tenaga pengajar diharapkan dapat menyesuaikan pembelajaran mulai dari proses, kurikulum bahkan output pembelajaran. Program Studi Arsitektur Universitas Katolik Santo Thomas telah berdiri kurang lebih tiga puluh enam tahun yang lalu, selama beberapa tahun terakhir kondisi program studi semakin menurun dari beberapa aspek termasuk penurunan drastis jumlah mahasiswa. Kondisi pandemi Covid-19 ini semakin memperburuk keadaan, diperlukan inovasi-inovasi yang adaptif yang dapat diterapkan dalam situasi new normal atau tatanan baru ini. Terdapat banyak kendala pembelajaran selama berlangsungnya pandemi ini. Dalam kondisi tatanan baru ini, kreativitas dosen dituntut lebih banyak lagi. Variasi media, metode pengajaran dan materi pengajaran diselaraskan dengan karakteristik mahasiswa yang merupakan generasi ' $z$ '. Salah satu inovasi yang sedang dilakukan yaitu relaksasi kurikulum, beberapa mata kuliah merevisi output perkuliahan menjadi objek yang lebih sederhana tetapi tetap memenuhi kompentensi dasar.
\end{abstract}

Kata kunci: inovasi, adaptif, tatanan baru.

\begin{abstract}
Title: Adaptive Innovation of Architecture Learning in New Normal

The current conditions of the Covid-19 pandemic have brought many changes in the order of our society, including changes in the learning system. The lecturer is expected to adjust learning, starting from the process, curriculum, and even the output. Architecture Study Program in Santo Thomas Catholic University was established approximately thirty-six years ago. Over the last few years, the study program's condition has decreased from several aspects, including a drastic decrease in the number of students. The Covid-19 pandemic condition has made things worse, and adaptive innovations are needed that can be applied in this new normal situation. There are many obstacles during this pandemic. In this new condition, the creativity of lecturers is demanded even more. Variations in media, teaching methods, and teaching materials are aligned with the characteristics of students who are ' $z$ ' generations. One of the innovations that are being carried out is curriculum relaxation, in which some courses revise the output of lectures into simpler objects but still fulfill basic competencies.
\end{abstract}

Keywords: innovation, adaptive, new normal. 


\section{Pendahuluan}

Indonesia dan negara-negara lainnya sedang terpuruk akibat pandemi Covid-19. Kondisi saat ini telah membawa banyak perubahan dalam tatanan masyarakat kita, termasuk perubahan dalam tatanan pembelajaran. Pandemi Covid-19 yang sangat masif telah memaksa pemerintah untuk mengeluarkan kebijakan social distancing dan physical distancing guna mencegah meluasnya penularan virus. Kebijakan tersebut juga telah diimplementasikan dalam penyelenggaraan pendidikan nasional dengan dikeluarkannya Surat Edaran Mendikbud Nomor 3 Tahun 2020 tentang Pencegahan COVID-19 pada Satuan Pendidikan dan Surat Edaran Nomor 4 Tahun 2020 Tentang Pelaksanaan Kebijakan Pendidikan Dalam Masa Darurat Penyebaran Coronavirus (Covid-19) (Kemendikbud, 2020). Akibat kebijakan tersebut maka sistem perkuliahan daring dipandang sebagai salah satu alternatif sistem pembelajaran. Akan tetapi perlu dipertanyakan kembali apakah sistem pembelajaran daring tersebut merupakan solusi yang tepat untuk pembelajaran terkhusus untuk jurusan atau keilmuan tertentu, contohnya untuk keilmuan arsitektur yang selama ini dalam pembelajarannya membutuhkan interaksi langsung dan sangat intens. Kesiapan mental, baik itu mahasiswa maupun tenaga pengajar/dosen, juga perlu dipertimbangkan dalam sistem pembelajaran daring ini. Hampir sebagian besar perguruan tinggi selama ini terbiasa dengan sistem pembelajaran luring (tatap muka) sehingga dengan pergantian sistem pembelajaran daring ini maka tenaga pengajar diharapkan dapat menyesuaikan pembelajaran mulai dari proses, kurikulum bahkan output pembelajaran.

Pembelajaran daring banyak dilakukan karena dianggap memiliki beberapa kelebihan yaitu dapat dilakukan dimana saja dan kapan saja (time and place flexibility). Menjangkau peserta didik (mahasiswa) dalam cakupan yang luas (potential to reach a global audience) dan mempermudah penyempurnaan dan penyimpanan materi pembelajaran (easy updating of content as well as archivable capabilities) (Pratiwi, 2020).

Di sisi yang lain, pembelajaran daring juga memiliki beberapa kelemahan yaitu penggunaan jaringan internet yang membutuhkan infrastruktur yang memadai dan membutuhkan banyak biaya (Gunawan, Suranti, Fathoroni, 2020). Pembelajaran daring sudah merupakan suatu keharusan di era teknologi ini, semakin banyak model pembelajaran yang mengedepankan model pembelajaran daring. Media dan aplikasi daring bukan lagi berfungsi sebagai sumber materi tetapi juga telah menjadi alat utama pembelajaran.

Program Studi Arsitektur Universitas Katolik Santo Thomas telah berdiri kurang lebih tiga puluh enam tahun yang lalu, selama beberapa tahun terakhir kondisi program studi semakin menurun dari beberapa aspek termasuk penurunan drastis jumlah mahasiswa. Saat ini Program Studi Arsitektur Universitas Katolik Santo Thomas memiliki Akreditasi 'B'. Lebih dari lima bulan sistem pembelajaran daring telah dilaksanakan di Program Studi Arsitektur Universitas Katolik Santo Thomas. Terdapat kendala baik dari pihak mahasiswa maupun dari pihak tenaga pengajar/dosen itu sendiri. Penulis melakukan evaluasi sederhana untuk mengetahui bagaimana pelaksanaan sistem pengajaran daring ini telah berjalan dan 
mencari tahu bagaimana saran dari kedua belah pihak untuk kelanjutan sistem pembelajaran daring pada semester berikutnya.

\section{Metode}

Metode penelitian sederhana untuk evaluasi pembelajaran daring di Fakultas Teknik; Program studi Teknik Sipil dan Arsitektur Universitas Katolik Santo Thomas, adalah deskriptif kualitatif. Data primer adalah persepsi mahasiswa dan tenaga pengajar/dosen melalui kuesioner dengan aplikasi Google Form. Kuesioner diambil dari responden mahasiswa berjumlah 47 orang dan dosen berjumlah 12 orang.

Pada bagian lain dari tulisan ini diambil dari studi kasus atau pengalaman empiris dari penulis dan beberapa dosen di Program Studi Arsitektur Universitas Katolik Santo Thomas. Kuesioner terdiri atas 10 pertanyaan (tertutup dan terbuka) untuk mahasiswa dan 15 pertanyaan (tertutup dan terbuka) untuk dosen. Semua pertanyaan dikategorikan mulai dari proses pembelajaran, kurikulum dan output pembelajaran selama pembelajaran daring ini berlangsung. Evaluasi ini merupakan salah satu upaya asesmen atau penilaian sejauh mana sebuah program berjalan. Beberapa model asesmen yang dapat diterapkan dalam proses pembelajaran jarak jauh di antaranya adalah penilaian berbasis daring, penilaian portofolio dan penilaian diri atau self assessment (Ahmad, 2020).

\section{Hasil dan Pembahasan}

\section{Evaluasi Pembelajaran Daring}

Penulis melakukan evaluasi sederhana mengenai pembelajaran daring di Fakultas Teknik; Program Studi Teknik Sipil dan Arsitektur Universitas Katolik Santo Thomas. Metode yang digunakan dengan pengumpulan kuesioner melalui media Google Form, dengan responden 47 orang mahasiswa dan 12 orang dosen. Metode pembelajaran daring yang paling banyak digunakan yaitu Google Classroom dan aplikasi Zoom. Hal ini serupa dengan beberapa penelitian mengenai pembelajaran daring lainnya yang menyimpulkan bahwa pembelajaran google classroom termasuk dalam kategori cukup efektif (Sabran \& Sabara, 2019; Alim dkk., 2019).

\section{Kelancaran Proses Pembelajaran Daring (Mahasiswa)}

Berdasarkan hasil kuesioner disimpulkan bahwa 42 persen mahasiswa merasakan sistem pembelajaran daring kurang lancar (Gambar 1).
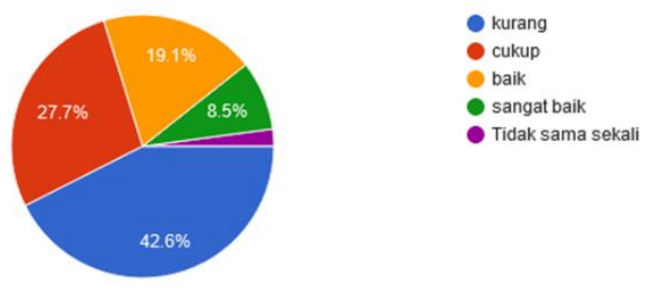

Gambar 1. Prosentase kelancaran pembelajaran daring Sumber: Analisis penulis, 2020 
Adapun alasan mahasiswa merasa kurang lancar di antaranya yaitu hambatan koneksi atau jaringan. Hampir semua mahasiswa telah kembali ke kampung halamannya masing-masing; sebagian besar di daerah sulit jangkauan koneksi seperti desa di Nias Barat, Nias Selatan, Humbang Hasundutan dan Tapanuli Utara. Sebahagian besar mahasiswa Fakultas Teknik berasal dari luar daerah (Gambar 2).

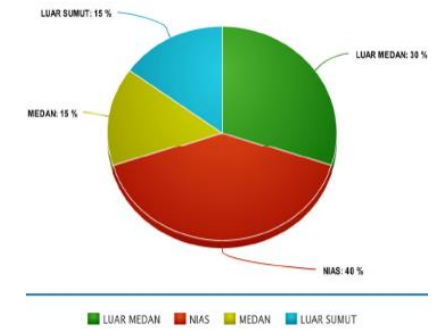

Gambar 2. Prosentase asal mahasiswa

Sumber: Program Studi Arsitektur Universitas Katolik St.Thomas, 2020

Mahasiswa juga mengungkapkan bahwa mereka belum terbiasa dan nyaman dengan sistem pembelajaran daring. Mereka merasa kurang memahami penjelasan dari dosen, kurang berinteraksi dan kurang puas dengan feedback dari dosen. Hal ini terutama dirasakan oleh mahasiswa Program Studi Arsitektur pada mata kuliah Studio. Pada jenis mata kuliah tersebut, sistem asistensi tugas studio tidak maksimal, terkendala jaringan dan interaksi yang kurang. Akibat berbagai permasalahan tersebut maka mahasiswa merasa kurang termotivasi untuk mengikuti pembelajaran daring (Gambar 3).

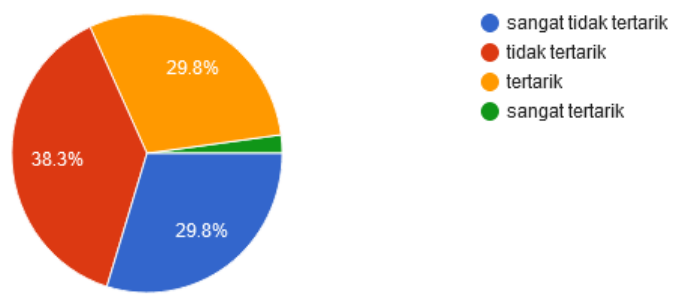

Gambar 3. Prosentase keinginan mengikuti pembelajaran daring Sumber: Analisis penulis, 2020

\section{Kelancaran Proses Pembelajaran Daring (Dosen)}

Dari hasil kuesioner terhadap 12 orang dosen, diketahui bahwa para dosen juga mengalami kesulitan dalam menjalankan sistem pembelajaran daring. Terdapat sekitar 75 persen dosen yang memerlukan tambahan waktu dari jumlah waktu mengajar luring. Mereka memerlukan berbagai bentuk bahan perkuliahan untuk dapat membuat mahasiswa memahami perkuliahan. Para dosen juga merasa kurang berinteraksi dengan mahasiswa dengan berbagai kendala; contohnya kendala sinyal.

Terdapat 50 persen dosen yang mengatakan bahwa pembelajaran daring ini sulit (Gambar 4). Oleh sebab itu mereka melakukan beberapa usaha untuk mempermudah pembelajaran daring ini dengan beberapa strategi seperti contohnya memperbanyak interaksi melalui tugas-tugas presentasi, memperkaya bahan 
perkuliahan dengan gambar dan video serta memberikan waktu yang lebih banyak dalam pengumpulan tugas (dispensasi).

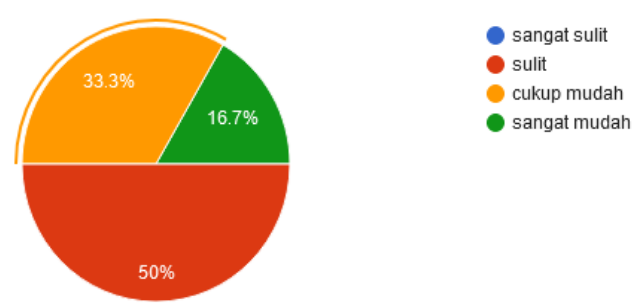

Gambar 4. Kelancaran pembelajaran daring (dosen) Sumber: Analisis penulis, 2020

\section{Pembelajaran Daring di Program Studi Arsitektur Universitas Katolik Santo Thomas}

Pada dasarnya seperti pada program studi lainnya, terdapat dua jenis mata kuliah di Program Studi Arsitektur Universitas Katolik Santo Thomas yaitu mata kuliah teori dan mata kuliah studio. Bagan alir mata kuliah Kurikulum KKNI 2017 dapat dilihat pada Gambar 6. Mata kuliah Studio merupakan mata kuliah yang paling banyak dipengaruhi oleh situasi pandemi ini. Dalam pelaksanaan luring sebelumnya, proses pembelajaran mata kuliah Studio bahkan melebihi ketentuan (Gambar 5). Metode blended method diterapkan oleh sebahagian besar dosen koordinator studio, walaupun demikian mahasiswa masih merasa tidak maksimal dalam pelaksanaannya. Jika dilihat dari Gambar 6, hampir di setiap semester terdapat mata kuliah studio yang memiliki prosentase SKS paling besar. Sistem pembelajaran daring yang kurang berhasil ini berdampak sangat besar dalam jumlah Indeks Prestasi Kumulatif mahasiswa.

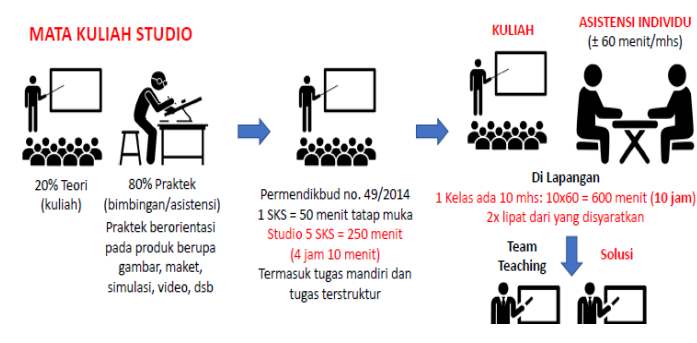

Gambar 5. Proses mata kuliah studio

Sumber: Program Studi Arsitektur Universitas Katolik St.Thomas, 2020

Sementara itu mata kuliah yang bersifat teori dilakukan secara daring dengan aplikasi Whatssapp Group, Google Classroom dan Zoom. Selama situasi pandemi ini, mata kuliah yang bersifat kerja praktik, kuliah lapangan dan penelitian ke daerah-daerah dihentikan untuk sementara waktu atau diubah sistem dan output pembelajarannya menyesuaikan dengan situasi saat ini. 


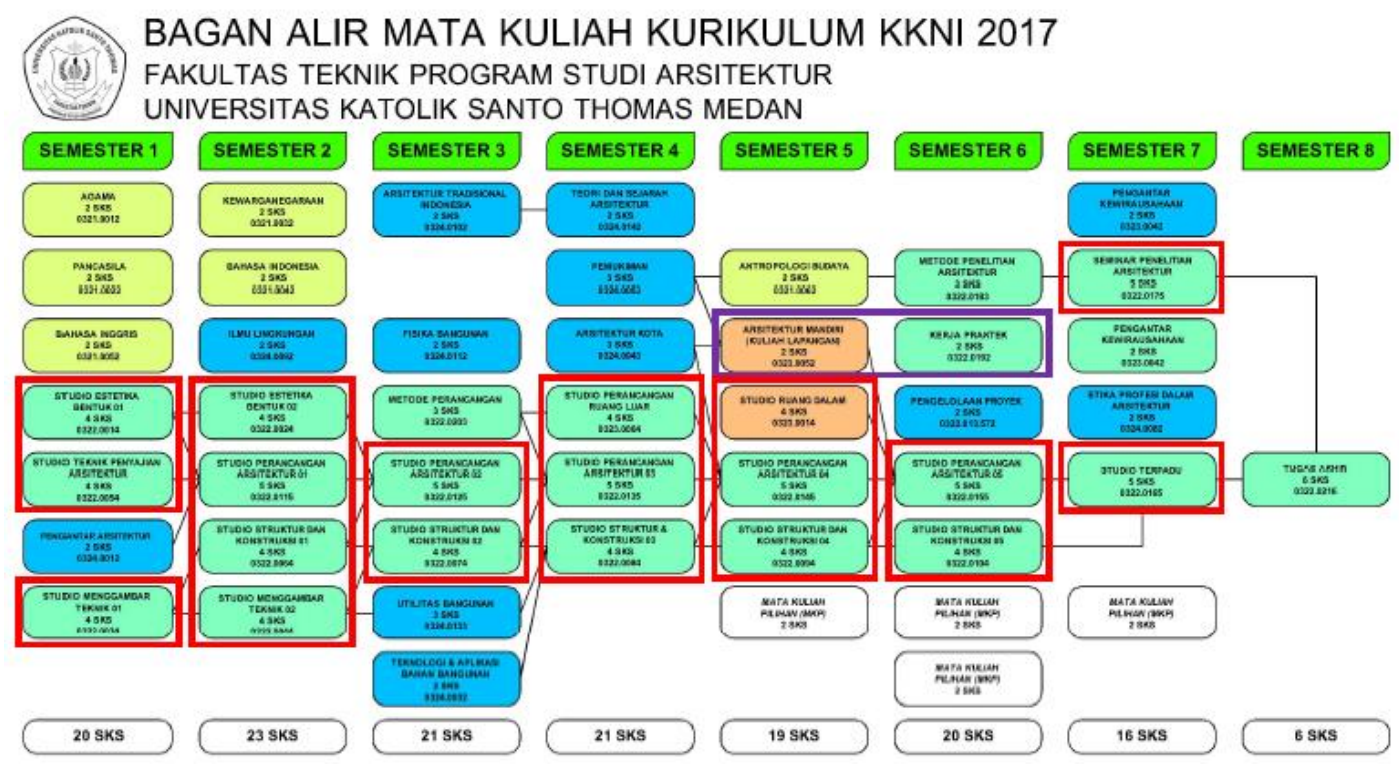

Gambar 6. Bagan alir kurikulum

Sumber: Program Studi Arsitektur Universitas Katolik St.Thomas, 2020

\section{Inovasi Adaptif Pembelajaran Daring}

Penulis mengalami banyak kendala selama pembelajaran daring ini, seringkali trial and error adalah proses yang paling banyak dilakukan. Berikut adalah beberapa inovasi yang telah dilakukan dalam mengadaptasi kondisi pandemi ini:

\section{Proses Pembelajaran}

Penulis melihat bahwa proses pembelajaran daring ini tidak sulit untuk dilakukan. Kendala sebagian besar dirasakan oleh dosen dengan umur di atas 50 tahun. Mereka kesulitan dalam mengaplikasikan sistem komputerisasi, sedangkan dosen-dosen yang lebih muda (berusia di bawah 50 tahun) tidak merasakan masalah teknologi ini. Oleh sebab itu pendampingan kepada dosen yang berumur di atas 50 tahun dapat dijadikan solusi; contohnya memaksimalkan dosen muda sebagai partner koordinator mata kuliah. Hal ini dilakukan di Program Studi Arsitektur Universitas Katolik Santo Thomas, contohnya pada mata kuliah Studio Perancangan Arsitektur. Mata kuliah tersebut dilaksanakan dengan sistem team teaching, yaitu satu mata kuliah dibawakan oleh 2-3 orang dosen dan dipimpin oleh dosen koordinator mata kuliah tersebut. Dengan sistem team teaching tersebut maka pembagian tugas/materi perkuliahan dapat disesuaikan dengan kondisi atau keahlian komputerisasi semua dosen. Dosen muda diberikan porsi yang lebih banyak dalam pembelajaran daring, sedangkan dosen yang sudah berumur diberikan porsi yang lebih sedikit atau tetap diberikan porsi yang sama hanya dalam penyampaian materi dibantu oleh dosen yang lebih muda. Biasanya aplikasi Zoom atau Google Classroom sangat sesuai dengan kondisi ini.

Google Classroom memiliki beberapa kelebihan untuk proses asistensi mata Kuliah Studio. Semua data tugas dapat kolektif tersimpan, memiliki fitur chat dan dapat langsung diberi nilai. 
Tabel 1. Inovasi pembelajaran daring di Program Studi Arsitektur Universitas Katolik Santo Thomas

\begin{tabular}{|c|c|c|c|c|}
\hline Mata Kuliah & SKS & $\begin{array}{c}\text { Proses } \\
1 \\
\end{array}$ & $\begin{array}{c}\text { Kurikulum } \\
2 \\
\end{array}$ & $\begin{array}{c}\text { Output Pembelajaran } \\
\mathbf{3} \\
\end{array}$ \\
\hline $\begin{array}{c}\text { Studio } \\
\text { Perancangan } \\
\text { Arsitektur 1, 3, } 5\end{array}$ & 4 & $\begin{array}{l}\text { Blended Method; } \\
\text { pemberian materi kuliah } \\
\text { melalui aplikasi Google } \\
\text { Classroom, Zoom dan } \\
\text { proses asistensi secara } \\
\text { luring, variasi materi } \\
\text { kuliah, video atau wajib } \\
\text { mengikuti webinar }\end{array}$ & $\begin{array}{l}\text { Relaksasi kurikulum; } \\
\text { penyederhanaan materi } \\
\text { perkuliahan, } \\
\text { penyederhanaan tugas, } \\
\text { contoh Ujian Tengah } \\
\text { Semester untuk SPA } 1 \\
\text { adalah menggambar ulang } \\
\text { rumah tinggal masing- } \\
\text { masing }\end{array}$ & $\begin{array}{l}\text { Menyederhanakan output } \\
\text { perkuliahan: } \\
\text { - } \text { rumah tinggal sederhana } \\
\text { (SPA 1), atau } \\
\text { - menyesuaikan kondisi } \\
\text { Pandemi Covid-19 } \\
\text { (Rumah sakit khusus } \\
\text { wabah/SPA 5) } \\
\text { - mengikuti lomba desain } \\
\text { 'Rumah Sederhana' } \\
\text { Universitas } 17 \text { Agustus } \\
\text { 1954 Jakarta (SPA 3) }\end{array}$ \\
\hline $\begin{array}{l}\text { Seminar } \\
\text { Arsitektur }\end{array}$ & 4 & $\begin{array}{l}\text { Sistem pembelajaran } \\
\text { daring dengan metode } \\
\text { Google Classroom, } \\
\text { Zoom, variasi materi } \\
\text { kuliah, video atau wajib } \\
\text { menjadi panitia webinar }\end{array}$ & $\begin{array}{l}\text { Relaksasi kurikulum; } \\
\text { penyederhanaan subjek } \\
\text { penelitian individu }\end{array}$ & $\begin{array}{l}\text { Output perkuliahan baru } \\
\text { yaitu Buku mengenai materi } \\
\text { penelitian kelompok; } \\
\text { kerjasama dengan partner } \\
\text { program studi yaitu } \\
\text { Museum Perkebunan } \\
\text { Indonesia }\end{array}$ \\
\hline $\begin{array}{l}\text { Arsitektur Kota } \\
\text { (Teori) }\end{array}$ & 2 & $\begin{array}{l}\text { Sistem pembelajaran } \\
\text { daring dengan metode } \\
\text { via Whatssapp Group, } \\
\text { Google Classroom, } \\
\text { Zoom }\end{array}$ & $\begin{array}{l}\text { Relaksasi kurikulum; } \\
\text { penyederhanaan subjek } \\
\text { berkaitan dengan observasi } \\
\text { lingkungan sekitar tempat } \\
\text { tinggal mahasiswa dan } \\
\text { fenomena selama pandemi } \\
\text { berlangsung }\end{array}$ & $\begin{array}{l}\text { Output perkuliahan } \\
\text { diperbanyak berupa essay } \\
\text { contoh: tugas membuat } \\
\text { essay untuk perlombaan } \\
\text { Menulis Mahasiswa } \\
\text { Kemendikbud mengenai ide } \\
\text { penanganan Covid-19 di } \\
\text { daerah masing-masing. }\end{array}$ \\
\hline $\begin{array}{c}\text { Cross } \\
\text { Program/Semester } \\
\text { Antara }\end{array}$ & 4 & $\begin{array}{l}\text { Blended Method; } \\
\text { pemberian materi kuliah } \\
\text { melalui aplikasi Google } \\
\text { Classroom, Zoom dan } \\
\text { proses asistensi secara } \\
\text { luring }\end{array}$ & $\begin{array}{l}\text { Relaksasi kurikulum; } \\
\text { penyederhanaan tugas-tugas } \\
\text { perkuliahan }\end{array}$ & $\begin{array}{l}\text { Output perkuliahan baru } \\
\text { yaitu buku mengenai materi } \\
\text { penelitian kelompok; buku } \\
\text { mengenai Arsitektur Nias } \\
\text { Selatan di Desa Hilinawalu } \\
\text { Fau }\end{array}$ \\
\hline
\end{tabular}

Sumber: Analisis penulis, 2020

Hal ini telah banyak ditemukan dari banyak penelitian serupa. Penelitian-penelitian tersebut melihat keunggulan Google Classroom sebagai alternatif terbaik pengajaran daring (Hakim, 2016); Google Classroom dipakai hampir 88 persen pendidikan vokasi di Indonesia (Gunawan \& Sunarwan, 2018 dalam Alim dkk, 2019), Google Classroom lebih efektif dalam menyampaikan materi (Ifthakhar, 2016).

Selain itu blended method atau metode gabungan merupakan metode pembelajaran yang dianggap lebih sesuai untuk mata kuliah studio. Pada mata kuliah studio, proses pemberian materi dilakukan secara daring dan proses asistensi dilakukan secara luring; dengan tetap menggunakan protokol kesehatan yang standar. Hal ini juga dilakukan untuk studio tugas akhir. Dosen di Program Studi Arsitektur Universitas Katolik Santo Thomas tidak melakukan kegiatan asistensi di ruangan 
dosen (luas ruang terbatas), tetapi memilih ruang yang lebih luas dengan sirkulasi udara yang lebih baik (ruang tunggu, ruang rapat).

Selain itu variasi bahan ajar adalah satu hal lain yang telah terbukti dapat meningkatkan minat mahasiswa untuk belajar. Hal ini juga dilatarbelakangi dengan karakter mahasiswa yang merupakan generasi ' $z$ ' (lahir tahun 1995-2014). Mengubah paradigma pembelajaran dari teacher centered ke student centered sangat memerlukan teknologi terkini, terkhusus bagi mahasiswa generasi ' $\mathrm{z}$ ' ini.

Metode variasi bahan ajar ini didukung hasil penelitian pembelajaran daring yang serupa sehingga didapatkan kesimpulan bahwa ada empat cara yang efektif dalam memberikan informasi mengenai media literasi yaitu pertama video yang disebarkan ke media sosial seperti YouTube dan Instagram. Cara yang kedua yaitu dengan membuat meme menarik dengan bahasa yang mudah dimengerti, cara yang ke tiga melalui selebgram yang menjadi panutan dan memiliki image positif dan cara terakhir melalui baliho di pinggir jalan. Temuan menarik lainnya adalah informan laki-laki cenderung menyukai informasi media literasi melalui video dan meme yang disebarkan ke media sosial, sementara perempuan lebih menyukai kampanye yang dilakukan oleh selebgram yang memiliki image positif dan pemakaian baliho (Rastati, 2018). Hal serupa juga terjadi pada mahasiswa Arsitektur Program Studi Arsitektur Universitas Katolik Santo Thomas dimana ditemukan persepsi yang menyatakan hal yang sama.

\section{Relaksasi Kurikulum}

Relaksasi kurikulum merupakan satu hal yang banyak dilakukan oleh dosen di Program Studi Arsitektur Universitas Katolik Santo Thomas. Relaksasi tersebut berupa penyederhanaan materi, penyesuaian materi dengan kondisi Pandemi Covid19 dan penambahan waktu pengumpulan tugas.

\section{Penyederhanaan Output Pembelajaran}

Penyederhanaan output pembelajaran juga merupakan salah satu hal yang banyak dilakukan di Program Studi Arsitektur Universitas Katolik Santo Thomas. Contohnya yaitu penyederhanaan output mata kuliah Seminar Arsitektur. Output yang seharusnya adalah laporan penelitian kelompok dan penelitian individu disederhanakan menjadi satu output yaitu laporan penelitian kelompok, tetapi dalam format sebuah buku yang siap untuk didaftarkan ISBN dan dicetak.

Selain itu tugas-tugas mata kuliah studio juga disederhanakan output pembelajarannya, seperti contohnya menyederhanakan tugas Studio Perancangan Arsitektur 1 menjadi menggambar ulang rumah tinggal masing-masing atau mengobservasi lingkungan tempat tinggal sekitar mahasiswa.

\section{Kesimpulan}

Situasi pandemi Covid-19 yang sedang berlangsung saat ini telah banyak mengubah tatanan dalam dunia pendidikan tinggi, terkhusus bagi keilmuan di bidang arsitektur. Sistem pembelajaran daring merupakan salah satu langkah yang dianggap paling tepat untuk sementara ini dan tidak menutup kemungkinan untuk 
tahun-tahun selanjutnya. Tenaga pengajar/dosen dituntut untuk lebih banyak belajar, lebih banyak menemukan solusi atau mengembangkan cara yang selama ini telah dilakukan. Setiap langkah harus lebih bervariasi dan adaptif kondisi; mulai dari proses pembelajaran, kurikulum dan output pembelajaran.

Program Studi Arsitektur Universitas Katolik Santo Thomas telah melakukan sistem pembelajaran daring dan menemukan banyak kendala selama lebih dari lima bulan pelaksanaan. Proses pembelajaran blended method, relaksasi kurikulum dan variasi materi perkuliahan merupakan beberapa best practice yang telah dilakukan dan memberikan dampak positif kepada para mahasiswa.

\section{Daftar Pustaka}

Ahmad, I.F. (2020). Alternative assesement in distance learning in emergencies spread of Corona Virus Disease (Covid-19) in Indonesia. Jurnal Pedagogik, Vol. 07, No. 01, 195-222.

Alim, N., Linda, W., Gunawan, F., Saad, M.S.M. (2019). The effectiveness of Google Classroom as an instructional media: a case of State Islamic Institute of Kendari, Indonesia. Humanities \& Social Sciences Reviews, Vol 7, No 2, 240-246.

Gunawan, Suranti, N.M.Y., Fathoroni. (2020). Variations of models and learning platforms for prospective teachers during the Covid-19 pandemic period. Indonesian Journal of Teacher Education, Vol. 1, No. 2, 61-70.

Hakim, A.B. (2016). Efektifitas penggunaan e-learning Moodle, Google Classroom dan Edmodo. I-STATEMENT, Vol. 2, No. 1, 1-6.

Iftakhar, S. (2016). Google classroom: What works and how?. Journal of Education and Social Sciences, Vol. 3, No. 1, 12-18.

Kemdikbud RI. (2020). Surat Edaran Menteri Pendidikan dan Kebudayaan Republik Indonesia nomor 3 tahun 2020 tentang Pencegahan Corona Virus Disease (Covid-19) pada Satuan Pendidikan. Jakarta: Kemendikbud RI.

Pratiwi, E.W. (2020). Dampak Covid-19 terhadap kegiatan pembelajaran online di sebuah perguruan tinggi Kristen di Indonesia. PERSPEKTIF Ilmu Pendidikan, Vol. 34, No. 1, 1-8.

Program Studi Arsitektur Universitas Katolik Santo Thomas. (2020). Bahan presentasi, Universitas Katolik Santo Thomas, 2020. Tidak dipublikasikan.

Rastati, R. (2018). Media literasi bagi digital natives: perspektif generasi z di Jakarta. Jurnal Teknologi Pendidikan, Vol. 6, No. 1, 60-73.

Sabran, Sabara, E. (2019). Keefektivan Google Classroom sebagai media pembelajaran. Prosiding Seminar Nasional Lembaga Penelitian Universitas Negeri Makassar "Diseminasi Hasil Penelitian melalui Optimalisasi Sinta dan Hak Kekayaan Intelektual”, 122-125. 